\title{
Analysis Factors Affecting Accounting Organization in Pharmaceutical Producing Enterprises in Vietnam
}

\author{
Nguyen Thi Phuong Dung \\ Nam Dinh University of Technology Education \\ E-mail: dungspkt79@gmail.com
}

Received: Oct. 25, 2020 Accepted: Dec. 17, $2020 \quad$ Published: Dec. 23, 2020

doi:10.5296/ifb.v7i2.18107 URL: http://dx.doi.org/10.5296/ifb.v7i2.18107

\begin{abstract}
This study analyzes and evaluates the factors affecting the organization of the accounting work in pharmaceutical manufacturing enterprises in Vietnam in the current period. The study uses both qualitative and quantitative research methods. Research data was collected from 156 surveys, implemented for subjects including directors, deputy directors, chief accountants, accountants of 48 pharmaceutical manufacturing enterprises in Vietnam. Data were processed using SPSS 22.0 software.
\end{abstract}

Keywords: factors affecting, accounting organization, pharmaceutical manufacturing enterprises in Vietnam 


\section{Introduction}

Vietnam's economy is increasingly integrated into the economies of other countries in the world, creating pressure for domestic businesses. To have a foothold in the market, enterprises must improve their competitiveness, improve production and business efficiency, and dominate the market. In which, the accounting activities in the enterprise plays an important role. By properly and fully calculating the input factors, well organize the collection, processing, analysis, and information provision to serve the business management requirements. The disclosure and transparency of corporate financial information are one of the mandatory requirements. Therefore, it requires accurate, fast, and effective accounting information. Accounting organization plays an important role in the production and business activities of each enterprise.

Accounting organization is one of the contents of management organizations in enterprises. The accounting organization must be suitable for the characteristics of the business operations, the size, and management requirements of the enterprise. Pharmaceutical is a specific industry because products are directly related to the health and safety of people, and therefore have an important position in the national economy and social life. The accounting organization of Vietnamese pharmaceutical manufacturing enterprises still has many limitations such as in the system of documents, accounts, accounting books, accounting checks, the recording of data, the accounting reports did not fully meet the information requirements.

Therefore, the analysis of the factors affecting the accounting organization in the pharmaceutical manufacturing enterprises of Vietnam is the basis for the enterprise to improve and renovate the accounting work organization, to contribute to improving the efficiency of accounting and management of pharmaceutical manufacturing enterprises in Vietnam is extremely necessary.

\section{Literature Review}

\subsection{The Views on the Organization of the Accounting in the Enterprise}

Accounting is an important tool to manage, administer, inspect, and supervise financial and economic activities in enterprises. The information provided by the accountant is the basis for making decisions on management and administration. On the other hand, it is also the basis for creating revenue and expenditure estimates, monitoring the implementation of the budget, and making the final settlement. All accountants must organize accounting.

Accounting organization in an enterprise is the determination of tasks and contents that an accountant must perform to form an accounting system that meets the requirements of the enterprise; It is essential to make use of the advantages of information technology in accounting organizations so that they are effective and efficient (Nguyen Phuoc Bao An et al., 2012).

In addition to organizing the application of accounting principles and methods to receive, process, and provide economic and financial information for economic management in the 
units, there are also people-related to the accounting apparatus (Do Minh Thanh et al., 2009).

Another viewpoint is that the organization of the accounting work is the relationship that constitutes the nature of accounting: accounting vouchers, account reciprocal, price calculation, synthesis-accounting balance. This point of view does not consider the organization of the accounting apparatus a part of the accounting work organization (Nguyen Thi Dong et al., 2014).

Accounting organization means an organization that receives, systematizes, and provides all information on production, business, and use of funds in the unit to serve the economic and financial management in units (Le Gia Luc, 1999). Work contents of accounting organizations in enterprises include organizations that receive accounting information; systematize and process accounting information; providing accounting information and organizing the accounting apparatus, and applying information technology in accounting activities.

Based on studying the above views on accounting organization, the author found that there are many different approaches to accounting organization, but according to the author's point of view:

Firstly, with the function of information, check the operating situation of the business in a regular, continuous, and systematic manner. The accounting organization in an enterprise must, first of all, be the process of receiving, processing, and providing information about the economic and financial activities of an enterprise based on applying accounting methods.

Secondly, in terms of personnel in the organization of the accounting apparatus, this is an important object that determines the success of the accounting work, so it should receive attention and focus. In current conditions, calculating the number of people needed for the accounting apparatus and assigning tasks to each person is very necessary, ensuring optimal human resource management, helping to optimize minimizing personnel costs for businesses.

Third, at present, $100 \%$ of enterprises have applied information technology to accounting work by applying accounting software or accounting applications on excel. Applying information technology in Industry 4.0, accounting software is capable of creating an integrated information system linking the accounting department with other departments inside and outside the enterprise. Create an effective integrated information system, quickly and promptly respond to the provision of information to managers. Modern facilities and software applications of information technology are considered to be an effective means of supporting accounting organizations.

Fourth, the accounting organization must match the scale and characteristics of the production and business organization and specific management requirements of the enterprise. The accounting organization is not only the organization of a management apparatus in the enterprise but also includes the establishment of factors and the impacting relationships between departments to the accounting work.

Based on the above analysis, according to the author, accounting organization is the 
collection, processing, and provision of accounting information based on applying accounting methods. Organize accounting inspection; to organize material foundations of information technology means for accounting; organize the accounting apparatus to suit the production and business characteristics of the enterprise to provide useful information for users to make effective decisions.

\subsection{The Fundamental Theories About the Factors Affecting the Accounting Organization in Manufacturing Enterprises}

There are many studies based on theories built to describe the relationships between the factors affecting the accounting work of the enterprise. In which, two typical theories are commonly used such as useful information theory and organizational structure theory.

\subsubsection{Useful Information Theory}

Useful information theory was introduced in the 1960s and started the orientation period on using useful accounting information to serve the right decision. This theory is considered the fundamental theory to build international accounting standards. Useful information theory emphasizes the fundamental task of financial reporting is to provide information that is useful and relevant for its users in economic decision-making. On the other hand, this theory is aimed at the usefulness of information to users rather than responding to the requirements of law.

- Influence of useful information theory on accounting organization in enterprises

Useful information theory emphasizes the basic task of accounting is to satisfy the information needs of its users. Due to the influence of this theory, when organizing the accounting in the enterprise, it is necessary to solve two main problems: (1) Ensuring the harmony between the accounting information users and the information usage needs; (2) Evaluate the usefulness of accounting information for each subject.

Useful information theory is the basis for evaluating the effectiveness and effects of using information for decisions. Useful information theory also helps users of different information to have an objective assessment of the quality of information on the financial statements of the enterprise.

Financial statements provide financial information useful for current and potential investors, creditors in decision making regarding the provision of resources to the business.

Financial statements provide useful financial information on assets, equity, revenue, and expenses for users of financial statements in reviewing net cash flows and evaluating the management of the unit's economic resources.

\subsubsection{Organizational Structure Theory}

According to Phan Thanh Tu et al. (2018): "Organizational structure of an organization is a set of functional parts and legitimate relationships between them, allowing to define the tasks that each part of the business must take over, fulfill, as well as modes of cooperation between departments." 
An organization can be structured in many different ways, depending on its purpose. The structure of an organization determines how it operates. An organization's performance depends on organizational structure, changing environment, strategy, technology, size, and culture (Chenhall, 2007).

- The influence of the organizational structure theory on the accounting work organization

According to the theory of organizational structure, accounting organization in an enterprise is the process of adjusting the appropriateness of an accounting organization to changes in an organization. Variables such as the organization's operating environment, the government's regulations, the size and structure of the enterprise have an influence on the accounting working group in the enterprise.

\subsection{Factors Affecting the Accounting Organization in Enterprises}

Published studies show that many factors are affecting the organization of accounting work in enterprises (Table 1). 


\section{Macrothink}

International Finance and Banking

ISSN 2374-2089

2020, Vol. 7, No. 2

Table 1. Summary of studies on the influencing factors to organize the accounting in the enterprise

\begin{tabular}{|c|c|c|}
\hline No. & Authors & Factors \\
\hline \multirow[t]{3}{*}{1} & \multirow{3}{*}{$\begin{array}{l}\text { Abdel-Kader and Luther } \\
\text { (2008) }\end{array}$} & 1. External factors: Environment and customer \\
\hline & & $\begin{array}{l}\text { 2. Internal factors: Competitive strategy, decentralization of } \\
\text { management and enterprise size }\end{array}$ \\
\hline & & $\begin{array}{l}\text { 3. Group of production process factors: production process, quality } \\
\text { management, inventory management }\end{array}$ \\
\hline \multirow[t]{4}{*}{2} & \multirow[t]{4}{*}{ Nguyen Dang Huy (2011) } & 1. Applying science and technology \\
\hline & & 2. Legal environment \\
\hline & & 3. Organizational management \\
\hline & & 4. Production and business organization of the enterprises \\
\hline \multirow[t]{5}{*}{3} & \multirow[t]{5}{*}{ Ahmad (2012) } & 1. The competitive level of the market \\
\hline & & 2. Enterprise Size \\
\hline & & 3. Technological and technical factors \\
\hline & & 4. The attention of the administrator \\
\hline & & 5. Qualifications of accountants \\
\hline 4 & Halbouni (2014) & 1. Information technology \\
\hline \multirow[t]{2}{*}{5} & \multirow[t]{2}{*}{ Ngo Thanh Nam (2017) } & $\begin{array}{l}\text { 1. External factors: Legal system, scientific and technological } \\
\text { achievements }\end{array}$ \\
\hline & & $\begin{array}{l}\text { 2. Internal factors: Characteristics of production and business } \\
\text { organization; require corporate governance; human factors; financial } \\
\text { resources of the enterprises }\end{array}$ \\
\hline \multirow[t]{5}{*}{6} & \multirow[t]{5}{*}{ Bui Tien Dung (2018) } & 1. Competition level of the market \\
\hline & & 2. Technological and production engineering factors \\
\hline & & 3. Business size \\
\hline & & 4. Administrator Involvement \\
\hline & & 5. Qualifications of accountants \\
\hline \multirow[t]{10}{*}{7} & \multirow[t]{10}{*}{ Bui Phuong Thanh (2018) } & 1. Objective factors \\
\hline & & - IT applications \\
\hline & & - Regulatory environment \\
\hline & & - Subjects using accounting information \\
\hline & & 2. Subjective factors \\
\hline & & - Business size \\
\hline & & - Perceptions of business owners \\
\hline & & - Enterprise management requirements \\
\hline & & - Qualifications of accountants \\
\hline & & - Characteristics of business organization and enterprise management \\
\hline \multirow[t]{5}{*}{8} & \multirow[t]{5}{*}{ Đao Ngoc Ha (2019) } & $\begin{array}{l}\text { 1. Characteristics of the business and production organization and the } \\
\text { management organization of the enterprise }\end{array}$ \\
\hline & & 2. Accounting legal system \\
\hline & & 3. Human resources for accounting \\
\hline & & 4. The level of concern of the enterprise \\
\hline & & 5. Facilities \\
\hline
\end{tabular}




\section{Macrothink}

Thus, there are many ways to approach the factors that affect the accounting organization in the business. However, in this study, 05 factors affect accounting organizations the most, including the legal environment of accounting, specific characteristics of enterprises, information technology, the business owner's awareness of the accounting organization, the capacity of accountants in the business.

\section{Research Methods}

The research uses primary data from direct in-company surveys. The purpose of the survey is to collect information, assessments, and perceptions of business owners, managers, chief accountants, and accountants in pharmaceutical manufacturing enterprises about the influencing factors to the accounting, organization to check the suitability of the theoretical model and adjust the model accordingly. At the same time, through investigative surveys to explore, adjust and supplement the observed variables used to measure research concepts, ensuring that the scale is built in a way that is consistent with the theory and is specified materialized by reality. Research using quantitative methods, evaluating the factors affecting the accounting organization in enterprises. The study used SPSS 22.0 analysis software.

\subsection{Research Hypothesis}

Hypothesis H1: The legal environment has a positive impact on the accounting organization of pharmaceutical manufacturing enterprises

Hypothesis H2: The specifics of the enterprise have a positive impact on the accounting organization of the pharmaceutical manufacturing enterprise

Hypothesis H3: Information technology has a positive impact on the accounting organization of pharmaceutical manufacturing enterprises

Hypothesis H4: The owner's perception of accounting organization has positive effects on the accounting organization of pharmaceutical manufacturing enterprises

Hypothesis H5: The capacity of the accountant in the enterprise has a positive impact on the accounting organization of the pharmaceutical manufacturing enterprise. 


\subsection{Research Model}

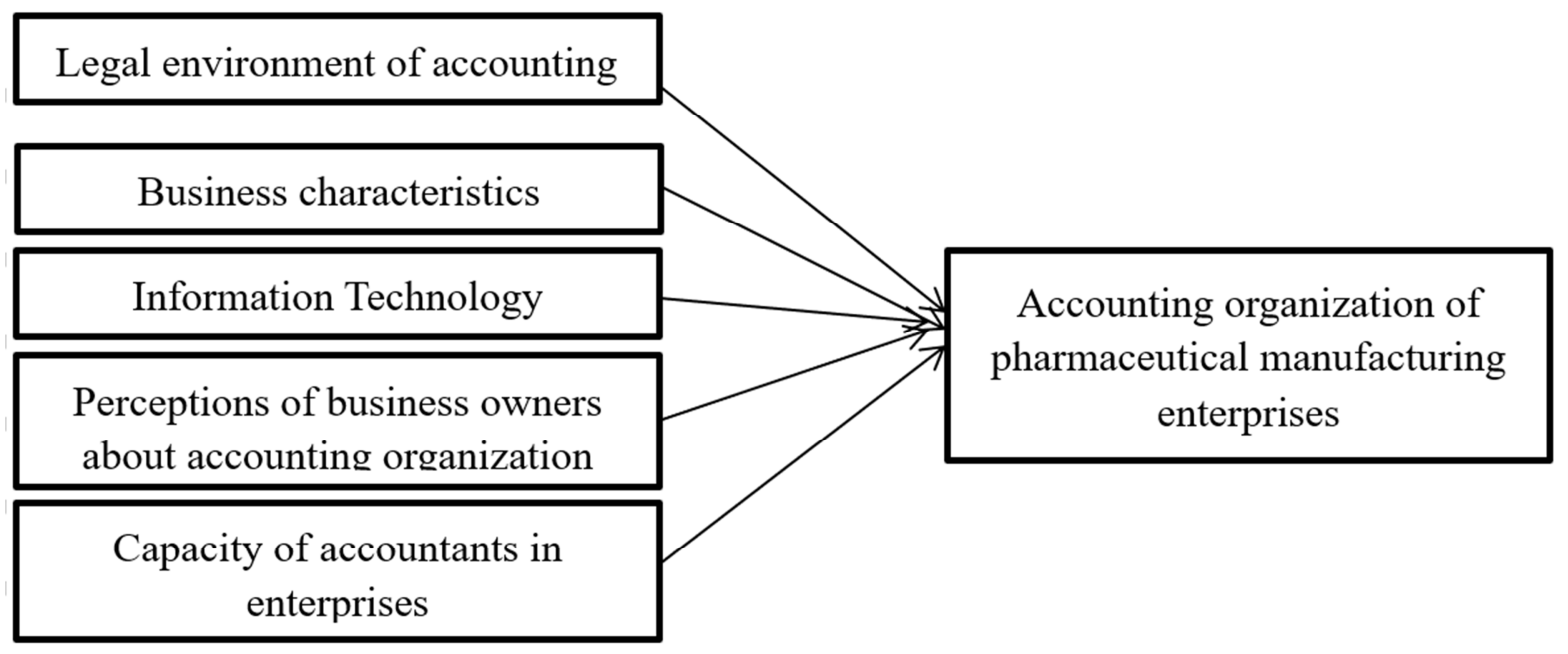

Figure 1. Research model

\section{Research Results and Discussion}

Survey results collected are 156 surveys from accountants, managers of businesses. The sample is determined according to Nguyen Dinh Tho (2013), with the minimum sample size for Exploratory Factor Analysis (EFA) research is at least 50 and better than 100 samples, the minimum rate of observation/variable is $5 / 1$. Thus, with 20 items measuring 06 factors, the minimum sample size is 100 . The survey results collected 156 questionnaires to ensure the necessary sample size.

With the research model above in Section 3.2, the author performed descriptive statistical estimation, regression analysis, and tests using SPSS 22.0 software.

\subsection{Evaluate the Scale}

Author verifying and evaluating the scale through analyzing the reliability of the scale by Cronbach Alpha and Exploratory Factor Analysis (EFA).

\subsubsection{Analyzing the Reliability of the Scale}

The results of analyzing the reliability of the scale, using Cronbach's Alpha for observed variables are described in Table 2. 
Table 2. Summary of test scales for independent and dependent variables

\begin{tabular}{|c|c|c|c|c|}
\hline No. & Variables & Variables name & $\begin{array}{l}\text { Variable } \\
\text { correlation } \\
\text { - total } \\
\end{array}$ & $\begin{array}{l}\text { Cronbach } \\
\text { Alpha } \\
\text { coefficient }\end{array}$ \\
\hline \multicolumn{5}{|c|}{ Legal environment of accounting (LEEN), Cronbach's Alpha $=.931$} \\
\hline 1 & LEEN01 & $\begin{array}{l}\text { The current accounting law, accounting standards, and } \\
\text { technical disciplines are the legal basis for the } \\
\text { accounting organization in the enterprise }\end{array}$ & .894 & .872 \\
\hline 2 & LEEN02 & $\begin{array}{l}\text { The openness and flexibility of the corporate accounting } \\
\text { regime create conditions for ENTERPRISES to improve } \\
\text { efficiency of accounting organization }\end{array}$ & .864 & .899 \\
\hline 3 & LEEN03 & $\begin{array}{l}\text { Accounting regime according to current guidelines is } \\
\text { clear and complete and meets the needs of recording and } \\
\text { processing data of enterprises. }\end{array}$ & .842 & .923 \\
\hline \multicolumn{5}{|c|}{ Business characteristics (BUCHA), Cronbach's Alpha $=.898$} \\
\hline 4 & BUCHA01 & Accounting organization based on firm size & .783 & .877 \\
\hline 5 & BUCHA02 & $\begin{array}{l}\text { Accounting organization based on the characteristics of } \\
\text { production and business organization }\end{array}$ & .815 & .841 \\
\hline 6 & BUCHA03 & Accounting organization based on business strategy & .821 & .849 \\
\hline \multicolumn{5}{|c|}{ Information Technology (INTE), Cronbach's Alpha $=.879$} \\
\hline 7 & INTE01 & $\begin{array}{l}\text { The hardware system and network in use have met the } \\
\text { accounting work at the enterprise }\end{array}$ & .794 & .809 \\
\hline 8 & INTE02 & $\begin{array}{l}\text { The accounting software in use has met the accounting } \\
\text { work in the enterprises }\end{array}$ & 673 & .907 \\
\hline 9 & INTE03 & $\begin{array}{l}\text { Enterprises make investment plans and develop } \\
\text { information technology to serve production and business } \\
\text { activities and accounting work at enterprises. }\end{array}$ & .873 & .735 \\
\hline \multicolumn{5}{|c|}{ Perceptions of business owners about accounting organization $($ PEOW), Cronbach's Alpha $=.953$} \\
\hline 10 & PEOW01 & $\begin{array}{l}\text { The business owner reads and understands the } \\
\text { information on financial report }\end{array}$ & .873 & .957 \\
\hline 11 & PEOW02 & $\begin{array}{l}\text { The information in the accounting report is the basis for } \\
\text { the enterprise owner to make management decisions }\end{array}$ & .955 & .890 \\
\hline 12 & PEOW03 & $\begin{array}{l}\text { The business owner understands the importance of } \\
\text { accounting organization in the enterprise and focuses on } \\
\text { investing in facilities and improving the capacity of } \\
\text { accountants }\end{array}$ & .891 & .943 \\
\hline \multicolumn{5}{|c|}{ Capacity of accountants in enterprises $($ CAAC), Cronbach's Alpha $=.887$} \\
\hline 13 & CAAC01 & $\begin{array}{l}\text { The professional capacity of accountants to meet the } \\
\text { enterprise management requirements }\end{array}$ & .595 & .909 \\
\hline 14 & CAAC02 & $\begin{array}{l}\text { The accountant has information technology capability, } \\
\text { software processing ability and foreign language ability. }\end{array}$ & .752 & .857 \\
\hline 15 & CAAC03 & $\begin{array}{l}\text { Accountants have skills in communication, behavior, } \\
\text { dynamism, creativity, and pressure from work }\end{array}$ & .853 & .833 \\
\hline 16 & $\mathrm{CAAC} 04$ & $\begin{array}{l}\text { The accountant has professional ethics that meets the } \\
\text { standards of accounting law }\end{array}$ & .914 & .808 \\
\hline \multicolumn{5}{|c|}{ Accounting organization of pharmaceutical manufacturing enterprises (ACOR), Cronbach's Alpha =0.908 } \\
\hline 17 & ACOR01 & $\begin{array}{l}\text { Organizing documents, accounts, books, and accounting } \\
\text { reports at the enterprise in good compliance with the } \\
\text { current legal regulations }\end{array}$ & .770 & .895 \\
\hline 18 & ACOR02 & $\begin{array}{l}\text { Accounting apparatus suitable for the size of your } \\
\text { business }\end{array}$ & .839 & .866 \\
\hline 19 & ACOR03 & $\begin{array}{l}\text { Current equipment and facilities of the unit to meet the } \\
\text { needs of data entry and information recording of the } \\
\text { accountant }\end{array}$ & .769 & .889 \\
\hline 20 & ACOR04 & $\begin{array}{l}\text { Accounting information provided promptly and fully to } \\
\text { meet the decision-making needs of information users }\end{array}$ & .810 & .875 \\
\hline
\end{tabular}

Source: Author calculated by SPSS Software. 
Analysis results of Cronbach's Alpha for the scales provided that the Cronbach Alpha coefficient of the variable group is $\geq 0.6$ and the total variable correlation coefficient $\geq 0.3$, if the Cronbach Alpha system increases, the type of variable will be considered observed. From the results Table 2 shows, the measurement scales of the variables are reliable.

\subsubsection{Exploratory Factor Analysis EFA}

After assessing the reliability of the scale, the author conducted Exploratory Factor Analysis EFA to evaluate the convergence and differentiation value of the scales.

- Factor analysis for independent variables

Table 3. Results of Exploratory Factor Analysis EFA for independent variables

\begin{tabular}{lll}
\hline KMO and Bartlett's Test & \\
\hline Kaiser-Meyer-Olkin Measure of Sampling Adequacy. & .642 \\
\hline Bartlett's Test of Sphericity & Approx. Chi-Square & 2625.330 \\
& df & 120 \\
& Sig. & .000 \\
\hline
\end{tabular}

Rotated Component Matrix ${ }^{\mathrm{a}}$

\begin{tabular}{|c|c|c|c|c|c|}
\hline & \multicolumn{5}{|c|}{ Component } \\
\hline & 1 & 2 & 3 & 4 & 5 \\
\hline$\overline{\mathrm{CAAC} 04}$ & .880 & & & & \\
\hline CAAC03 & .861 & & & & \\
\hline CAAC02 & .853 & & & & \\
\hline CAAC01 & .694 & & & & \\
\hline PEOW03 & & .961 & & & \\
\hline PEOW 02 & & .946 & & & \\
\hline PEOW 01 & & .899 & & & \\
\hline LEEN01 & & & .904 & & \\
\hline LEEN 02 & & & .896 & & \\
\hline LEEN 03 & & & .861 & & \\
\hline INTE03 & & & & .907 & \\
\hline INTE01 & & & & .870 & \\
\hline INTE02 & & & & .834 & \\
\hline BUCHA02 & & & & & .916 \\
\hline BUCHA03 & & & & & .892 \\
\hline BUCHAP01 & & & & & .865 \\
\hline Eigenvalues & 5.654 & 2.690 & 2.273 & 1.786 & 1.361 \\
\hline $\begin{array}{l}\text { Average Variance } \\
\text { Extracted }\end{array}$ & 35.339 & 52.149 & 66.355 & 77.520 & 86.029 \\
\hline
\end{tabular}

Source: Author calculated by SPSS Software

The results of exploratory factor analysis (EFA) with observed variables affecting the accounting organization of pharmaceutical manufacturing enterprises showed good results. 


\section{Macrothink}

That is shown in coefficient $\mathrm{KMO}=0.642$ corresponding to significance level $\mathrm{Sig}=0.000<$ $5 \%$. This result indicates that the research data is consistent with the research model.

Besides, the Cumulative of Variance of factor 5 and the convergence coefficient eigenvalues of this factor are $86.029 \%>50 \%$ and $1.361>1$, respectively, this result also shows that in the first observed variables, there is a convergence of 5 factors and these factors explain $86.029 \%$ of the variation of survey data.

Besides, the matrix rotates the factors that show the factor loading coefficients of the observed variables are greater than 0.5 . Thus, after performing exploratory factor analysis EFA ensures the ability to represent the initial survey data and are eligible to perform multivariate regression. Five factors extracted after performing EFA analysis, including: (1) Legal Environment of Accounting (LEEN); (2) Business Characteristics (BUCHA); (3) Information Technology (INTE); (4) Perceptions of Business owners about accounting organization (PEOW); Capacity of accountants in enterprises (CAAC).

- Exploratory factor analysis for the dependent variable

Table 4. Exploratory factor analysis for the dependent variable

\begin{tabular}{ll}
\hline Variables observation & Factor Loading \\
\hline ACOR02 & .910 \\
ACOR 04 & .895 \\
ACOR03 & .878 \\
ACOR01 & .871 \\
Eigenvalues & 3.160 \\
Average Variance Extracted & 78.993 \\
KMO & .598 \\
Sig & 0.000 \\
\hline
\end{tabular}

Source: Author calculated by SPSS Software.

Based on the above results, it shows that 04 observed variables have converged on one factor with the coefficient $\mathrm{KMO}=.598$ with significance level $\mathrm{sig}=0.000<5 \%$, the variance extracted is $78.993 \%$. That confirmed convergence and good representation of the dependent variables.

\subsection{Test Models and Hypotheses}

The study performed multivariate regression analysis with 5 independent variables and the selection method was Enter. Results of multivariate regression analysis are as follows: 
Table 5. Summary of regression model

\section{Model Summary}

\begin{tabular}{lllll}
\hline Model & $\mathrm{R}$ & R Square & Adjusted R Square & Std. Error of the Estimate \\
\hline 1 & $.690^{\mathrm{a}}$ & .476 & .414 & .23375
\end{tabular}

Note. a. Predictors: (Constant), CAAC, POEW, INTE, BUCHA, LEEN.

ANOVA $^{\mathrm{a}}$

\begin{tabular}{|c|c|c|c|c|c|c|}
\hline \multicolumn{2}{|c|}{ Model } & \multirow{2}{*}{$\frac{\text { Sum of Squares }}{2.882}$} & \multirow{2}{*}{$\begin{array}{l}\mathrm{df} \\
5\end{array}$} & \multirow{2}{*}{$\begin{array}{l}\text { Mean Square } \\
.576\end{array}$} & \multirow{2}{*}{$\begin{array}{l}\mathrm{F} \\
10.549\end{array}$} & \multirow{2}{*}{$\begin{array}{l}\text { Sig. } \\
.000^{\mathrm{b}}\end{array}$} \\
\hline 1 & Regression & & & & & \\
\hline & Residual & 8.196 & 150 & .055 & & \\
\hline & Total & 11.078 & 155 & & & \\
\hline
\end{tabular}

Note. a. Dependent Variable: ACOR. b. Predictors (Constant), CAAC, POEW, INTE, BUCHA, LEEN.

\section{Coefficients $^{\mathrm{a}}$}

\begin{tabular}{|c|c|c|c|c|c|c|c|c|}
\hline \multirow{2}{*}{\multicolumn{2}{|c|}{ Model }} & \multicolumn{2}{|c|}{$\begin{array}{l}\text { Unstandardized } \\
\text { Cofficients }\end{array}$} & \multirow{2}{*}{$\begin{array}{l}\text { Standardized } \\
\text { Cofficients } \\
\text { Beta }\end{array}$} & \multirow[t]{2}{*}{$\mathrm{t}$} & \multirow[t]{2}{*}{ Sig. } & \multicolumn{2}{|c|}{ Collinearity Statistics } \\
\hline & & $\overline{\mathrm{B}}$ & Std. Error & & & & Tolerance & VIF \\
\hline \multirow[t]{6}{*}{1} & (Constant) & .009 & .139 & & 6.483 & .000 & & \\
\hline & LEEN & .042 & .056 & .163 & .473 & .029 & .513 & 1.706 \\
\hline & BUCHA & .257 & .073 & .286 & 1.066 & .000 & .746 & 1.353 \\
\hline & INTE & .098 & .068 & .197 & 1.438 & .022 & .727 & 1.592 \\
\hline & PEOW & .208 & .065 & .228 & 1.417 & .034 & .738 & 1.405 \\
\hline & CAAC & .203 & .080 & .203 & 6.020 & .027 & .782 & 1.343 \\
\hline
\end{tabular}

Note. a. Dependent Variable: ACOR.

The results of the model show that $\mathrm{R} 2$ is 0.372 , which means that $37.2 \%$ of the variation of the dependent variable of the accounting organization of the pharmaceutical manufacturing enterprise is generally explained by the independent variables in the model. The model's conformity test results also showed that F-test had Sig value. $=.000<5 \%$, proving that the research model of the thesis is suitable for the data set under investigation.

From the results of the model, the independent variables LEEN, BUCHA, INTE, PEOW, CAA are statistically significant with the significance level Sig. $<0.05$. The results of the regression model also show that the tolerance coefficient (Tolerance) is high (from 0.513 to 0.782), and the magnification coefficient of VIF is low (from 1.343 to 1.706) less than 2. Based on that, we can conclude that the relationship between these independent variables is insignificant and does not occur multicollinearity.

From the results of the regression model we can draw multiple regression equations representing the relationship between the independent variables and the dependent variable as 
follows:

\section{ACOR $=0.009+0.042$ LEEN + 0.257 BUCHA + 0.098 INTE + 0.208 PEOW +0.203 CAAC}

In which: ACOR is the dependent variable representing the accounting organization of pharmaceutical manufacturing enterprises. Independent variables are: (1) Legal environment of accounting (LEEN); (2) Business Characteristics (BUCHA); (3) Information Technology (INTE); (4) Perceptions of business owners about accounting organization (PEOW); (5) Capacity of accountants in enterprises (CAAC).

\subsection{Discuss the Results of the Multivariate Regression Model}

The results of the scale regression with the explanation through R2 was $47.6 \%$, showing the good results of the independent variables, compared with the author's model Dao Ngoc Ha (2019). The test results show that all 5 hypotheses of the model are accepted.

Five factors affect the accounting organization in the pharmaceutical manufacturing enterprise are: (1) Legal environment of accounting (LEEN); (2) Business Characteristics (BUCHA); (3) Information Technology (INTE); (4) Perceptions of business owners about accounting organization (PEOW); (5) Capacity of accountants in enterprises (CAAC).

Among the 5 factors affecting the accounting organization of pharmaceutical manufacturing enterprises, the factor "Business Characteristics" has the largest impact with the standardized regression coefficient Beta $=0.286$. The factor "Perceptions of the business owners about accounting organization" has a standardized regression coefficient Beta $=0.228$.

The factor "Capacity of the accountant in enterprises" has a lower impact on the return coefficient with Beta standardized $=0.203$. The factor "Information Technology" has a lower impact on the standardized regression coefficient Beta $=0.197$. The factor "Legal environment of accounting" with the standardized regression coefficient Beta $=0.163$ is the factor that has the least impact on the accounting organization of pharmaceutical manufacturing enterprises.

Based on these results, for pharmaceutical manufacturing enterprises, the specific factors of the business including business size, business lines, production and business organization, and business strategy have the most influence on the accounting organization. Large-scale pharmaceutical manufacturing enterprises compared to small-sized businesses will have a large number of transactions, so the system of documents, accounts, books, financial statement will organize a larger and larger scale to keep track of the transactions on time and to provide accurate information.

Administrators are the people who have an important role in deciding the allocation of resources of the accounting apparatus. Therefore, the management's perception of the accounting work has the second-largest influence among the 05 factors on the accounting organization in the researched pharmaceutical manufacturing enterprises.

The accounting staff is the person who directly implements and performs the accounting 
work of the enterprise, so the qualifications and capacity of the accounting team is the third influence on the enterprise accounting organization.

The application of information technology to production and business will reduce the differences in accounting organizations, increase the efficiency of accounting organizations in enterprises. The survey shows that pharmaceutical enterprises have applied accounting software but have not yet invested in the application of fast and synchronous processing of technical information technology in accounting organizations, with a small number of enterprises applies modern systems such as ERP.

And finally, the legal factor also has a positive influence on the accounting organization in the pharmaceutical companies but has the lowest impact of the 5 factors.

\section{Conclusions and Recommendations}

The research has contributed to completing the scales, testing the model, pointing out the factors affecting the accounting organization in providing useful accounting information for administrators at pharmaceutical manufacturing enterprises in Vietnam.

The research results show 05 factors that have the most positive impact on the accounting organization in pharmaceutical manufacturing enterprises.

These factors are: (1) Legal environment of accounting (LEEN); (2) Business Characteristics (BUCHA); (3) Information Technology (INTE); (4) Perceptions of business owners about accounting organization (PEOW); (5) Capacity of accountants in enterprises (CAAC).

To improve the operational efficiency of the accounting organization in pharmaceutical manufacturing enterprises in Vietnam, it is necessary to pay attention to the following issues:

Firstly, on the legal environment of accounting. The State needs to perfect the accounting policy regime according to international accounting practices, in accordance with the legal system and the qualifications of the current Vietnamese accounting team.

Second, about the business characteristics. This is a subjective factor from the self of enterprises, this factor has a strong impact on the organization of the accounting work of each enterprise. The accounting information provided must meet the management requirements of each business.

Thirdly, to increase the application of information technology in accounting work organizations. It is necessary to promote the investment of hardware and software equipment in accounting to help reduce the working time of accountants and provide information quickly, and the quality of information is improved.

Fourth, raising perceptions of business owners in improving accounting work organizations.

Fifth, attention should be paid to the training of human resources in the accounting apparatus, raising awareness, professional skills, and software processing skills of accountants. It is necessary to assign labor in a scientific and reasonable accounting apparatus to avoid overlapping in work. 


\section{References}

Đào, N. H. (2019). Hoàn thiện TỔ CHỨC KẾ TOÁN tại các công ty CP tu vấn thiết kế của Việt Nam. Học viện Tài chính..

Davis, R. (2015). Industry 4.0. Digitalisation for productivity and growth, Briefing for the European Parliament. European Parliamentary Research Service, September 2015.

Dellon, W. H., \& Ephraim, R. M. (2003). The Delon and McLean Model of Information Systems Success: A Ten Years Update. Journal of Management Information Systems, 19(4), 9-30. https://doi.org/10.1080/07421222.2003.11045748

Lê Gia, L. c. b. (1999). Tổ chức công tác kế toán. NXB Tài chính, Hà Nội.

Lưu Đức, T. v. c. s. (2011). Giáo trình tổ chức công tác kế toán trong doanh nghiệp. NXB Tài chính, Hà Nội.

Ngô, T. H. (chủ biên). (2016). Tổ chức công tác kế toán. NXB Chính trị quốc gia - Sự thật.

Nguyễn, T. T. L. (2016). Giáo trình Tổ chức công tác kế toán. NXB Thống kê.

\section{Copyright Disclaimer}

Copyright for this article is retained by the author(s), with first publication rights granted to the journal.

This is an open-access article distributed under the terms and conditions of the Creative Commons Attribution license (http://creativecommons.org/licenses/by/4.0/). 